\title{
Prevalence of the absence of palmaris longus muscle assessed by a new examination test (Hiz-Ediz Test) in the population residing in the area of Van, Turkey
}

\author{
Yeni bir muayene tekniği ile (Hız-Ediz Test) palmaris longus kası yokluğunun \\ Van, Türkiye yöresinde ikamet eden popïlasyondaki prevelansı
}

\author{
Özcan Hiz ${ }^{1}$, Levent Ediz ${ }^{1}$, Mehmet Fethi Ceylan ${ }^{2}$, Emrullah Gezici ${ }^{1}$, Elif Gülcü ${ }^{1}$, Metin Erden ${ }^{1}$ \\ ${ }^{1}$ Department of Physical Therapy and Rehabilitation, Yüzüncü Yıl University, Medical Faculty, Van, Turkey \\ ${ }^{2}$ Department of Orthopaedic Surgery, University of Yüzüncü Yıl, Medical School, Van, Turkey
}

\begin{abstract}
Objectives: The primary goal of this trial was to show the compatibility between a new test technique (Hiz-Ediz test) for detection of palmaris longus muscle (PLM) agenesis, which we recently developed, and the former tests, the Schaeffer and Mishra's second tests.
\end{abstract}

Materials and methods: One thousand cases were enrolled in this trial. Schaeffer's test, Mishra's second test and Hiz-Ediz tests were applied to all cases. Examinations were performed to determine differences between genders and both hands. Consistency between all three tests was investigated.

Results: In the Hiz-Ediz test, PLM agenesis was determined in $15.1 \%$. No significant difference was found between the rates of unilateral and bilateral tendon agenesis determined by three tests ( $p>0.05)$. When the consistency of the three tests was evaluated using the kappa test, full consistency was determined between Mishra's second and the Hiz-Ediz test; however, full consistency was not determined between the Schaffer's and the other two tests. But, no statistical difference was found between the three tests.

Conclusion: Our results indicate that the prevalence of PLM agenesis is consistent with the available data. The Hiz-Ediz test can be applied easily and safely to determine and to visualize the PLM agenesis, when compared to the Mishra's second test and the Schaeffer's test. J Clin Exp Invest 2011; 2 (3): 254-259.

Key words: Palmaris longus muscle, tendon, agenesis, assessment, Turkey, Hiz-Ediz test

\section{ÖZET}

Amaç: Bu çalışmanın ana amacı Palmaris Longus Kası (PLK) agenezinin tespiti için yeni geliştirdiğimiz bir test tekniği ile (Hız-Ediz test), önceki testler arasındaki (Schaeffer ve Mishra ikinci testleri) arasındaki uyumluluğu göstermek idi.

Gereç ve yöntem: Bu çalışmaya 1000 olgu alındı. Tüm olgulara Schaeffer testi, Mishra ikinci testi ve Hız-Ediz testi uygulandı. Cinsiyetler ve her iki el arasındaki farklar tespit edilmeye çalışıldı. Her üç test arasındaki tutarlılık araştırıldı.

Bulgular: Hız-Ediz testinde, PLK agenezi olguların \%15.1'inde tespit edildi. Üç test tarafından tespit edilen unilateral ve bilateral tendon agenezi oranları açısından testler arasında herhangi bir fark yoktu $(p>0.05)$. Her üç testin tutarlılığı kappa test ile değerlendirildiğinde Mishra ikinci test ve Hız-Ediz test arasında tam tutarlılık tespit edildi; bununla birlikte Schaeffer ve diğer iki test arasında tam tutarlılık tespit edilmedi. Ancak, üç test arasında istatistiksel bir fark bulunmadı.

Sonuç: PLK agenezi prevelansının textbook bilgileri ile uyumlu olduğunu göstermektedir. Hız-Ediz testi, Mishra ve Schaeffer ikinci testleri ile kıyaslandığında PLK agenezisini görmede ve tespit etmede kolay ve güvenilir olarak uygulanabilir. Klin Deney Ar Derg 2011; 2 (3): 254-259.

Anahtar kelimeler: Palmaris longus kası, tendon, agenezi, değerlendirme, Türkiye, Hız-Ediz test 


\section{INTRODUCTION}

Palmaris Longus muscle (PLM) is a slender muscle, arising from the medial epicondyl by the common flexor tendon and the adjacent intermuscular septa. It extends with a long tendon, and is located rather superficially in the anterior compartement of the forearm and passes from the anterior of the flexor retinaculum. A few fibers detach from the tendon and intertwine with the transverse fibers of the retinaculum. The tendon intercrosses the retinaculum, broadens as a flat plate and is inserted into the palmar aponeurosis. A feature of this muscle is that it has a short body and a long tendon. ${ }^{1}$ The palmaris longus is one of the most variable muscles in the musculoskeletal system. Its absence is the most prevalent state among all muscle agenesis cases. ${ }^{2}$ Variations of the palmaris longus muscle were classified in five groups by Schlafly and Lister $^{3}$ : classical, double, reverse, central and bifida.

The palmaris longus is a muscle which lost its function with the erection of the human being during evolution and gradually became extinct. Thus, it is accepted as an inessential muscle because the functions of the hand and wrist are not affected in the absence of PLM. ${ }^{4}$ On the other hand, it is clinically important due to its frequent use in hand surgery and reconstructive surgery. ${ }^{5}$

Most of the standard textbooks on hand surgery report the prevalence of the absence of the palmaris longus as $15 \% \cdot{ }^{6-8}$ On the other hand; it is well known that wide variations exist in prevalence reports of PLM agenesis in various ethnic groups. In one trial, the rate of PLM muscle agenesis in the Turkish population was reported to be high; this rate was reported as $63,9 \%$ in the general population. ${ }^{9}$ In another trial conducted in the Turkish population, this rate was reported as $26,59 \% .{ }^{10}$ It is acceptable to find different results in various populations, but variable results in the same population is an unexpected finding. The finding of highly variable results in these two trials conducted in similar populations may be due to the characteristics of the population selected and to tests used for diagnostic purposes. Up to date, a number of different tests (Schaeffer's technique, Thompson's technique, Mishra's first test, Mishra's second test, Pushpakumar's test and Thompson's test) have been described to determine the presence of PLM. ${ }^{11-17}$ Most recently, Gangata ${ }^{18}$ recommended a new test. In trials related to PLM tendon agenesis, the most frequently used tests are the Schaeffer and the Mishra second tests, and the newly developed tests are compared against these tests.

These tests have certain advantages and disadvantages. While some can be implemented easily, they do not fully display the presence of the muscle; some tests precisely show the presence of the muscle, but they are not easily implemented. The highly variable results in the prevalence of PLM agenesis in the Turkish population indicate a visualization problem in the test used; this has led us to develop a new and easy test technique in order to better visualize the PLM. Thus, in determining the presence of PLM, reliable tests are needed which explicitly show the muscle and which can at the same time be applied easily. With this in mind, we developed a new test which is a combination of the Schaeffer and the Mishra tests.

The primary goal of this trial was to determine the prevalence of PLM agenesis in the Turkish population; the second goal was to show the consistency between our newly developed Hiz-Ediz test and the former tests, Schaeffer and Mishra's second tests.

\section{MATERIALS AND METHODS}

This trial was conducted on patients and relatives of patients between 18-30 years of age, living in the Van area, who had presented to the hospital between January 2010-August 2010 with various complaints.

Cases with normal wrist and wrist joints were enrolled in the trial. Individiuals with a history of surgical operation or injury in the upper extremities, those with a history of neurological and rheumatological diseases and patients with upper extremity disorders and abnormalities were excluded from this study.

The initial evaluation of the palmaris longus tendon was performed by the standard test of Schaeffer. The cases were further examined using the Mishra's second test and finally, by our recently developed Hiz-Ediz test.

Standard test (Schaeffer's test): the subject is asked to oppose the thumb to the little finger and then flex the wrist (Figure 1). 
Mishra's test II: the subject is asked to abduct the thumb againts resistance with the wrist in slight palmar flexion (Figure 2).

Hiz-Ediz test: This was performed by applying resistance to flexion of fingers and wrist while all fingers were at the opposite position with the wrist at slight flexion (Figure 3).

All of the three tests were applied on all cases by the same physician. When the PLM was not seen under the skin at the distal of the forearm on the wrist and was not palpated at the same position, the PLM was considered absent. The presence or absence of the palmaris longus on both sides, age, gender and the dominant hand were recorded.

\section{Statistical analysis}

The prevalence of unilateral or bilateral palmaris longus muscle agenesis was determined as percentages (\%). Palmaris longus tendon agenesis determined in three tests and in both genders were evaluated with the rate comparison method using the $\mathrm{z}$ test. The Kappa statistics was used in order to determine the consistency between the Schaeffer, Mishra and the Hiz-Ediz tests in detecting palmaris longus muscle agenesis. Statistical significance was regarded as 5\%. The SPSS 13 statistical package program was used for computations.

\section{RESULTS}

A total of 1000 cases, 500 women and 500 men were enrolled in this trial. The age range of cases was 1830 and the mean age was determined as 22.48 years. Nine hundred and forty two cases $(94.2 \%)$ had right dominant hands, while 58 cases $(5.8 \%)$ were left dominant. In the Schaeffer test, right agenesis was detected in 152 cases $(15.2 \%)$ and left agenesis was determined in 159 cases (15.9\%). In both Mishra and the Hiz-Ediz tests, right agenesis was detected in 144 cases $(14.4 \%)$ while left agenesis was determined in 151 cases (15.1\%). The Schaeffer test detected bilateral agenesis in 146 cases $(14.6 \%)$ and unilateral agenesis in 13 cases $(1.39 \%)$. In both the Mishra test and the Hiz-Ediz test, bilateral agenesis was detected in 138 cases $(13.8 \%)$ and unilateral agenesis was detected in 13 cases $(1.3 \%)$. No significant difference was found between the rates of unilateral and bilateral tendon agenesis detected by the three tests (Table 1).
According to the results of all three tests, no significant difference was found between unilateral and bilateral tendon agenesis rates in men and women (Table 2).

In terms of consistency between the three tests, complete consistency was detected between Mishra's second and the Hiz-Ediz tests (Table 3). On the other hand, complete consistency was not observed between the Schaeffer and the Hiz-Ediz tests and between Schaeffer and Mishra's second tests. Sixteen PLM which were detected as absent by the Schaeffer test was found to be present by Mishra and Hiz-Ediz tests (Table 4).

Table 1. Frequency of Palmaris longus tendon agenesis according to tests performed

\begin{tabular}{lllll}
\hline $\begin{array}{l}\text { PLM tendon } \\
\text { agenesis }\end{array}$ & Schaffer & Mishra & Hiz-Ediz & $p$ \\
\hline Bilateral & $146(14,6 \%)$ & $138(13,8 \%)$ & $138(13,8 \%)$ & 0,608 \\
Unilateral & $13(1,3 \%)$ & $13(1,3 \%)$ & $13(1,3 \%)$ & 1,000 \\
Total & $159(15,9 \%)$ & $151(15,1 \%)$ & $151(15,1 \%)$ & 0,621 \\
\hline
\end{tabular}

Table 2. Palmaris longus tendon agenesis rates in terms of gender, determined by the Mishra and Hiz-Ediz tests

\begin{tabular}{llll}
\hline PLM tendon agenesis & Men & Women & $p$ \\
\hline Unilateral (Right/Left) & $6(0,6 \%)(2 / 4)$ & $7(0,7 \%)(2 / 5)$ & 0,780 \\
Bilateral & $66(6,6 \%)$ & $72(7,2 \%)$ & 0,582 \\
Total & $72(7,2 \%)$ & $79(7,9 \%)$ & 0,536 \\
\hline
\end{tabular}

Table 3. Consistency between the Mishra and Hiz-Ediz test

\begin{tabular}{clll}
\hline & \multicolumn{2}{l}{ Hiz-Ediz test } \\
\hline Palmaris longus & Present & Absent \\
Mishra second test & Present & 1705 & 0 \\
& Absent & 0 & 295 \\
\hline
\end{tabular}

Kappa $\triangle$ Standard Error $=1,000 \triangle 0.000, p<0.001$

Table 4. Consistency between the Schaeffer and Hiz-Ediz test and Mishra's second test

\begin{tabular}{llll}
\hline & & \multicolumn{1}{l}{ Hiz-Ediz test and } \\
& Mishra Second Test \\
\hline \multirow{3}{*}{ Schaeffer test } & Palmaris longus & Present & Absent \\
\cline { 2 - 4 } & Present & 1689 & 0 \\
& Absent & 16 & 295 \\
\hline
\end{tabular}

Kappa $\triangle$ Standard Error $=0.968 \triangle 0.011, p<0.001$ 
Table 5. Rates of palmaris longus agenesis in various trials conducted in Turkey

\begin{tabular}{lcccc}
\hline & $\begin{array}{c}\text { Right } \\
(\%)\end{array}$ & $\begin{array}{c}\text { Left } \\
(\%)\end{array}$ & $\begin{array}{c}\text { Bilateral } \\
(\%)\end{array}$ & $\begin{array}{c}\text { Total } \\
(\%)\end{array}$ \\
\hline Ceyhan et al. (1997) & 8,4 & 12,2 & 43,2 & 63,8 \\
Kose et al. (2009) & 4,5 & 7,04 & 15,04 & 26,6 \\
Our study (2010) & 0,4 & 0,9 & 13,8 & 15,1 \\
\hline
\end{tabular}

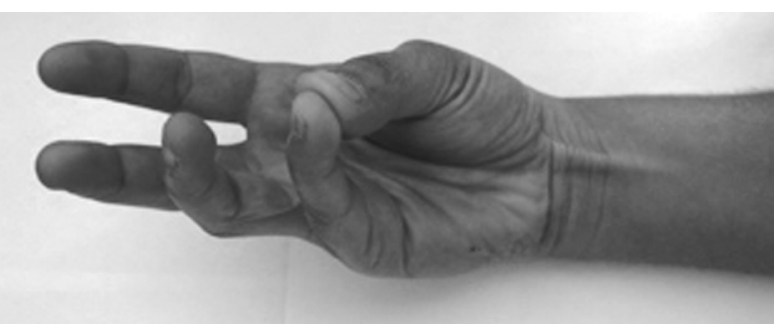

Figure 1. Schaeffer test for demonstrating the palmaris longus tendon.

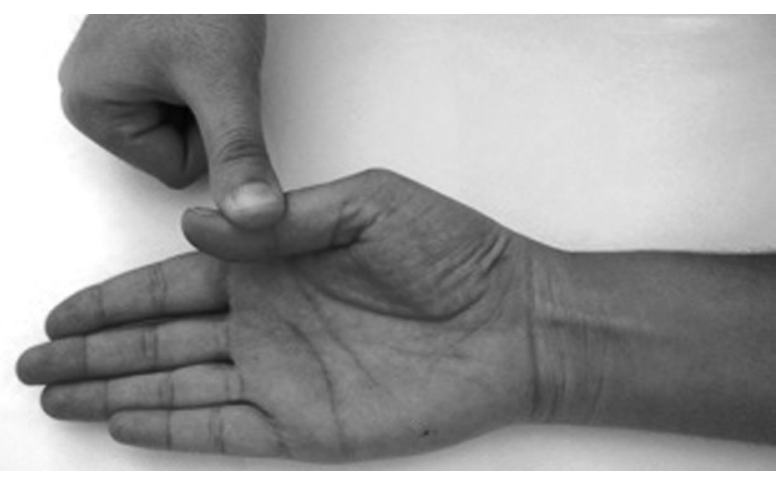

Figure 2. Mishra's second test for demonstrating the palmaris longus tendon.

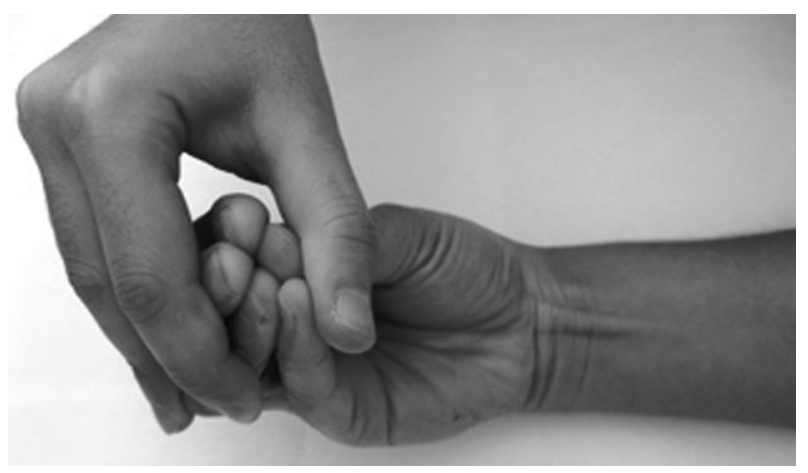

Figure 3. Hiz-Ediz test for demonstrating the palmaris longus tendon.

\section{DISCUSSION}

In this trial, PLM agenesis was tested using three different tests. According to our results, PLM agen- esis was detected as $15.9 \%$ by the Schaeffer test and as $15.1 \%$ by Mishra and Hiz-Ediz tests. There was no significant difference in the rate comparison between the three tests and full consistency was determined between Mishra's second and Hiz-Ediz tests as shown by the kappa test.

In many of the previous trials, the prevalence of PLM tendon agenesis has been reported at different rates in various ethnic groups. The prevalence was reported as $0.6 \%$ in the Korean population ${ }^{19}$ while it was reported as $1.5 \%$ in the black African population of Zimbabwe ${ }^{18}$ and as $63.9 \%$ in the Turkish population. ${ }^{9}$ In trials conducted in Europe and North America, the prevalence was reported between 5.5 and $24 \% .{ }^{20-25}$ On the other hand, rates between ${ }^{4,6}$ and $17.2 \%$ were detected in the Asian population. ${ }^{26-30} \mathrm{In}$ our country, considerably different results were obtained in two different trials conducted up to this date. ${ }^{9,10}$ The prevalence rates of previous trials in Turkey and in our trial have been presented in Table 5.

In the trial conducted by Ceyhan et al. ${ }^{9}$ the overall rate of PLM agenesis was reported as $63.6 \%$ and this is the highest rate in the literature up to this date. ${ }^{9}$ On the contrary, Kose et al. ${ }^{10}$ reported $26.6 \%$ overall prevalence in their trial. This high prevalence of PLM agenesis in these trials may indicate or be due to a visualization problem in the tests used in these trials. In our trial, the overall prevalence was determined to be lower than in other trials conducted in Turkey. On the other hand, it was similar to rates reported in other trials conducted worldwide. In our trial, we used the Hiz-Ediz test, which we recently developed, in addition to tests used by Kose et al. ${ }^{10}$ higher PLM agenesis rates were detected by the Schaeffer test when compared to Mishra's second and Hiz-Ediz tests, but there was no significant difference between them. Agenesis was detected in the same number of patients by Mishra and Hiz-Ediz tests. We believe that even though the Schaeffer test stands as the first described test, currently, there is no test of golden standard available. No validity and reliability studies were performed for these tests. This may only be achieved by post-mortem studies or by using imaging techniques. However, performing imaging techniques in this large population is difficult and costly. Therefore, studies comparing these tests are needed. 
There are controversial results in the literature regarding PLM agenesis between body sides and genders. Some authors report that agenesis is more frequent in women and on the left side of the body. ${ }^{21,27}$ In our country, PLM agenesis was found to be higher in women in the trial conducted by Kose et al. ${ }^{10}$ but no difference was found between body sides. However, in some of the other trials, no statistical difference was reported in terms of gender and body side..$^{23,28-30}$ In the trial conducted by Ceyhan et al. ${ }^{9}$ bilateral PLM agenesis was detected to be significantly higher in both genders, when compared to unilateral PLM agenesis. In another trial, unilateral PLM agenesis was found to be significantly higher when compared to bilateral PLM agenesis. ${ }^{31}$ We did not determine a statistically significant difference between genders. However, bilateral PLM agenesis was found to be higher in both genders when compared to unilateral PLM agenesis.

Various examination methods have been described for detection of PLM agenesis. ${ }^{11-17}$ The first test was described by Schaeffer et al. ${ }^{11}$ On the other hand, as recommended by Kose et al. ${ }^{10}$, this method may not be sufficiently reliable in cases where the muscle is weak and PLM tendon may be inadvertently regarded as absent. PLM is the weak flexor of the wrist. Furthermore, it plays a role in stabilization of the palmar fascia, in addition to anteposition and pronation of the thumb. ${ }^{32}$ Mishra et al. ${ }^{13}$ described a new method (Mishra's second test), which is performed by applying resistance against abduction of the thumb. In a trial conducted by Kose et al. ${ }^{10}$, the presence of PLM was detected by Mishra's second test in 35 cases who were previously regarded as PLM agenesis cases by the Schaeffer test. Twenty three of these 35 cases were women. In line with these results, they recommended the use of at least two examination methods in order to improve reliability. Finally, in a new trial conducted in 2009, Gangata ${ }^{18}$ described a new technique in which resistance is applied against the thumb and wrist flexion. We tried to develop a test combining the features of both the Schaeffer's and Mishra's second tests and we described a new test which we called the Hiz-Ediz test. This test is applied by applying resistance against the fingers and wrist flexion while all fingers are at opposition position and the wrist is at slight flexion (Figure 3). Characteristics of this test are that it reflects the features of the Schaeffer and Mishra's second tests and it is applied easily. In the same cases, the presence of PLM was visualized at least at the same rates as in Schaeffer (Figure 1) and Mishra's second tests (Figure 2) or more effectively by our newly developed Hiz-Ediz test (Figure 3).

Prevalence of total PLM tendon agenesis was determined as $15,1 \%$ in the Van area of Turkey. This rate is quite similar to the rates indicated in textbooks. No difference was found between different genders and body sides. Bilateral PLM agenesis was determined to be significantly higher. The same rates were determined by Mishra's second test and by our new technique, the Hiz-ediz test. Therefore, we believe that this new test recommended by our group is reliable. When the results of our trial and other trials are compared, considerable differences are seen among different ethnic groups. However, variable results were found in three trials conducted in our country. This may be due to the tests applied or related to the test administrator. Therefore, further studies are needed on validity and reliability of all tests recommended up to this date.

Tendon grafts are needed in reconstructive surgery. The PLM tendon is an important tendon which is utilized for this purpose. Our results show that the rate of PLM presence is around $85 \%$ in the Van area. Therefore, in our area, PLM tendon still stands as an important donor in reconstructive surgery when needed. As in previous trials, it was not possible to indicate PLM variations by the tests applied in our trial. Post-mortem studies are needed to fully determine these variations. Reports of different prevalence rates in the same population indicate that comparative trials with imaging techniques such as MRI or USG are needed in order to show the validity and reliability of these tests.

\section{REFERENCES}

1. Standring S. Gray's anatomy, 39th edn. Elsevier Churchill Livingstone, Edinburg, 2005: 876-7.

2. Koo CC, Roberts AH. The palmaris longus tendon. Another variation in its anatomy. J Hand Surg Br 1997; 22(1): 138-9.

3. SchlaXy B, Lister G. Median nerve compression secondary to biWd reversed palmaris longus. J Hand Surg Am 1987; 12(3): 371-3.

4. Sebastin SJ, Lim AY, Bee WH, Wong TC, Methil BV. Does the absence of the palmaris longus aVect grip and pinch strength. J Hand Surg Br 2005; 30(4): 406-8.

5. Wehbe MA. Tendon graft donor sites. J Hand Surg Am 1992; 17(6): 1130-2. 
6. Kleinert HE, Pulvertaft RG, Smith DJ. Flexor tendon grafting in the hand. In: Jupiter JB (ed) Flynn's hand surgery. Williams \& Wilkins, Baltimore, 1991: 285.

7. Saldana MJ. Primary extensor tendon grafts in zones 5 to 7. In: Blair WE (ed) Techniques in hand surgery. Williams \& Wilkins, Baltimore, 1996: 587.

8. Smith P. Injury. In: Smith P (ed) Lister's the hand--diagnosis and indications. Churchill Livingstone, London, 2002: 11.

9. Ceyhan O, Mavt A. Distribution of agenesis of palmaris longus muscle in 12 to 18 years old age groups. Indian J Med Sci 1997: 51(5): 156-60.

10. Kose O, Adanir O, Cirpar M, Kurklu M, Komurcu M. The prevalence of absence of the palmaris longus: a study in Turkish population. Arch Orthop Trauma Surg 2009; 129(5): 609-11

11. Schaeffer TJ. On the variations of the palmaris longus muscle. Anat Rec 1909; 3: 275-8.

12. Zeybek A, Gurunluoglu R, Cavdar S, Bayramicli M. A clinical reminder: A palmaris longus muscle variation. Ann Plast Surg 1998; 41: 224-5.

13. Mishra S. Alternative tests in demonstrating the presence of the palmaris longus. Indian J Plastic Surg 2001; 34: 12.

14. Pushpakumar SB, Hanson RP, Carroll S. The 'two finger' sign. Clinical examination of palmaris longus (PL) tendon. Br J Plast Surg 2004; 57: 184-5.

15. Bhattacharya V, Raveendra Reddy G. The palmaris longus tendon-rationality of the finger manoeuvres. Br J Plast Surg 2005; 58: 419-21.

16. Mahajan AL. The 'fingers fan out' sign: Stick out your palmaris longus even better! Br J Plast Surg 2005; 58: 278-9.

17. Oudit D, Crawford L, Juma A, Howcroft A. The "fourfinger"sign: To demonstrate the palmaris longus tendon. Plast Reconstr Surg 2005; 116: 691-2.

18. Gangata $H$. The Clinical surface anatomy anomalies of the palmaris longus muscle in the Black African population of Zimbabwe and a proposed new testing technique. Clinical Anatomy 2009; 22(2): 230-5.

19. Ahn DS, Yoon ES, Koo SH, Park SH. A prospective study of the anatomic variations of the median nerve in the carpal tunnel in Asians. Ann Plast Surg 2000; 44(3): 282-7.
20. George R. Co-incidence of palmaris longus and plantaris muscles. Anat Rec 1953; 116(5): 521-3.

21. Reimann AF, Daseler EH, Anson BJ, Beaton LE. The palmaris longus muscle and tendon. A study of 1600 extremities. Anat Rec 1944; 89(4): 495-505.

22. Thompson JW, McBatts J, Danforth CH. Hereditary and racial variations in the musculus palmaris longus. Am J Phys Anthropol 1921; 4(3): 205-18.

23. Thompson NW, Mockford BJ, Cran GW. Absence of the palmaris longus muscle: a population study. Ulster Med J 2001; 70(1): 22-4.

24. Troha F, Baibak GJ, Kelleher JC. Frequency of the palmaris longus tendon in North American Caucasians. Ann Plast Surg 1990; 25(4): 477-8.

25. Vanderhooft E. The frequency of and relationship between the palmaris longus and plantaris tendons. Am J Orthop 1996; 25(1): 38-41.

26. Ito MM, Aoki M, Kida MY, Ishii S, Kumaki K, Tanaka S. Length and width of the tendinous portion of the palmaris longus: a cadaver study of adult Japanese. J Hand Surg Am 2001; 26(4): 706-10.

27. Kapoor SK, Tiwari A, Kumar A, Bhatia R, Tantuway V, Kapoor S. Clinical relevance of palmaris longus agenesis: common anatomical aberration. Anat Sci Int 2008; 83(1): 45-8.

28. Roohi SA, Choon-Sian L, Shalimar A, Tan GH, Naicker AS. A study on the absence of palmaris longus in a multiracial population. Malays Orthop J 2007; 1(1): 26-8.

29. Sebastin SJ, Puhaindran ME, Lim AY, Lim IJ, Bee WH. The prevalence of absence of the palmaris longus - a study in a Chinese population and a review of the literature. J Hand Surg Br 2005; 30(5): 525-7.

30. Sebastin SJ, Lim AY. Clinical assessment of absence of the palmaris longus and its association with other anatomical anomalies, a Chinese population study. Ann Acad Med Singap 2006; 35(4): 249-53.

31. Erić M, Krivokuća D, Savović S, Leksan I, Vucinić N. Prevalence of the palmaris longus through clinical evaluation. Surg Radiol Anat 2010; 32(4): 357-61.

32. Fahrer M, Tubiana R. Palmaris longus, anteductor of the thumb. Hand 1976; 8(3): 287-9. 